\title{
Combination of swim-up and density gradient separation methods effectively eliminate DNA damaged sperm
}

\author{
Yüzdürme ve dansite gradient ayırma metotlarının kombinasyonu DNA hasarlı \\ spermleri etkili bir şekilde uzaklaştırır
}

\author{
Surveen Ghumman ${ }^{1}$, Satish Kumar Adiga ${ }^{1}$, Dinesh Upadhya ${ }^{1}$, Guruprasad Kalthur ${ }^{1}$, Varshini Jayaraman ${ }^{1}$, \\ Satish Bola Rao ${ }^{2}$, Pratap Kumar ${ }^{1}$ \\ ${ }^{\prime}$ Clinical Embryology, Division of Reproductive Medicine, Kasturba Medical College, Manipal University, Manipal, India \\ ${ }^{2}$ Department of Radiobiology and Toxicology, Manipal Life Science Centre, Manipal, India
}

\section{Abstract}

Objective: The aim of this experimental prospective study was to investigate the efficacy of single and combination sperm wash methods for their ability to isolate DNA intact spermatozoa.

Material and Methods: Sperm DNA damage was introduced by local testicular irradiation in male mice and the extent of damage was quantified by comet assay. The spermatozoa were subjected to single (swim up or density gradient method) and also a combination of sperm wash techniques. The DNA integrity in various sub-fractions of wash techniques was evaluated.

Results: The amount of DNA damaged sperm did not differ between individual fractions when single wash technique was applied. However, a combination of density gradient and swim-up techniques significantly reduced $(p<0.01)$ the number of DNA damaged sperm in the final population.

Conclusion: The combination of density gradient separation and swim-up method is effective in eliminating DNA damaged spermatozoa. (J Turkish-German Gynecol Assoc 2011; 12: 148-52)

Key words: Sperm wash, DNA damage, swim- up, density gradient separation, comet assay

Received: 13 June, 2011

Accepted: 19 July, 2011
Ozet

Amaç: Bu deneysel prospektif çalışmanın amacı tek ve kombinasyon sperm yıkama metotlarının, DNA'sı sağlam spermatozoa izolasyon etkinliklerini araştırmaktı.

Gereç ve Yöntemler: Sperm DNA hasarı erkek farelerde lokal testiküler ışınlama ile oluşturuldu ve hasarın büyüklüğü comet assay ile ölçüldü. Spermatozoa'ya tek (yüzdürme veya dansite gradient metodu) ve ayrica kombinasyon sperm ylkama teknikleri uygulandı. Yıkama tekniklerinin çeşitli alt fraksiyonlarında DNA'nın bütünlüğü değerlendirildi.

Bulgular: Tek yıkama tekniği uygulandığında DNA hasarlı sperm miktarı fraksiyonlar arasında farkllık göstermedi. Bununla beraber, dansite gradienti ve yüzdürme tekniklerinin kombinasyonu son popülasyondaki DNA hasarlı sperm sayısını anlamlı olarak $(\mathrm{p}<0.01)$ azalttı. Sonuç: Dansite gradient ayırma ve yüzdürme mettotlarının kombinasyonu DNA hasarlı spermatozoa'nın uzaklaştırılmasında etkilidir. (J Turkish-German Gynecol Assoc 2011; 12: 148-52)

Anahtar kelimeler: Sperm yıkama, DNA hasarı, yüzdürme, dansite gradient ayırma, comet assay

Geliș Tarihi: 13 Haziran 2010

Kabul Tarihi: 19 Temmuz 2011

\section{Introduction}

Sperm chromatin is a highly organized, compact structure consisting of DNA and heterogeneous nucleoproteins. There has been increased concern regarding the role of sperm DNA integrity in male infertility $(1,2)$. Sperm DNA integrity is essential for accurate transmission of genetic material to the offspring (3). It has been shown that paternal DNA damage can lead to pre-implantation developmental delay and compromised post-implantation developmental potential in mice (4-6). Hence sperm preparation method for assisted reproduction techniques should aim at minimizing the potential risk caused by abnormal sperm on the outcome. The established sperm preparation techniques used in the routine assisted reproductive technique laboratory vary in their ability to separate sperm carrying DNA abnormalities $(7,8)$. The most common laboratory techniques used in the extraction of functionally normal spermatozoa are swim-up or sperm migration and density gradient centrifugation (9). Although density gradient centrifugation is comparable to swim-up technique in recovering spermatozoa with enhanced motility, there is still controversy about the effects of density gradient centrifugation on sperm DNA integrity $(10,11)$. Recently, it has been shown that semen processing by density gradient centrifugation is not generally useful in selecting sperm with higher double-strand DNA integrity (12), although others have shown that sperm DNA/chromatin integrity improves after preparation by density gradient centrifugation (13-15). As there is still controversy and insufficient evidence concerning the ability of sperm preparation techniques for the elimination

Address for Correspondence: Satish Kumar Adiga, Ph.D., Clinical Embryology Laboratory Department of Obstetrics, Gynecology Kasturba Medical College Manipal University, Manipal-576 104, India Phone: 91-820-29-22027 Fax: 91-820-25-71934 e.mail: satish.adiga@manipal.edu

(C) Copyright 2011 by the Turkish-German Gynecological Education and Research Foundation - Available on-line at www.jtgga.org doi:10.5152/jtgga.2011.35 
of DNA damaged sperm in the ejaculate, we chose to use mouse sperm to determine the efficacy of the techniques. DNA damage was introduced by local testicular irradiation in male mice and the extent of damage was evaluated before and after various sperm processing methods, including all the sub fractions of the methods used to determine the efficacy.

\section{Methods}

\section{Animals}

Eight to twelve week old healthy Swiss Albino male mice were used for the experiments. At least five animals were used for each data point. Sperm DNA damage was induced by testicular irradiation. The Institutional Animal Ethical Committee's approval was obtained before performing the experiment.

\section{Testicular irradiation}

Male mice were anaesthetized using Ketamine $50 \mathrm{mg} / \mathrm{kg}$ body weight. The whole body except the testicular area was covered using a lead shield and the animals were exposed to 3 Gy gamma radiation at a rate of $1 \mathrm{~Gy} / \mathrm{min}$ from the $\mathrm{Co}^{60}$ teletherapy unit.

\section{Sperm extraction}

Seven days after irradiation, animals were sacrificed by cervical dislocation and spermatozoa were extracted from the cauda epididymis by squeezing the cauda epididymis in $1 \mathrm{ml}$ of prewarmed Earle's Balanced Salt Solution (EBSS, Cat No. E 2888, Sigma Chemical Co.). The sperm suspension was analyzed for DNA integrity by comet assay and the remainder of the sperm suspension was divided into three parts and used for various sperm preparation methods. The experiment was performed in duplicate.

\section{DNA damage analysis by Comet assay}

The DNA fragmentation in spermatozoa was assessed by the alkaline comet assay as described by Singh et al. (16) with minor modifications. Briefly, the spermatozoa were collected from the entire cauda epididymis in sterile phosphate buffered saline (pH 7.4) and centrifuged. Sperm density was kept constant by appropriate dilution in order to maintain the uniform distribution of the spermatozoa during electrophoresis. The sperm suspension was mixed with an equal volume of $0.8 \%$ low melting agarose (Cat No. A 9414, Sigma Chemical Co, USA) and layered on a slide pre-coated with $1 \%$ normal agarose (Cat No. 9539, Sigma Chemical Co, USA). A third coat of agarose was layered over the second layer followed by overnight incubation in lysing solution $(2.5 \mathrm{M} \mathrm{NaCl}, 100 \mathrm{mM}$ disodium EDTA, $10 \mathrm{mM}$ Trizma base, $\mathrm{pH}$ 10.1\% Triton X-100, 10mM GSH, and $100 \mu \mathrm{M}$ heparin) under alkaline conditions ( $\mathrm{pH} \mathrm{10)}$ at $4^{\circ} \mathrm{C}$. After sperm DNA unwinding in the electrophoresis buffer $(300 \mathrm{mM} \mathrm{NaOH}$, $1 \mathrm{mM}$ EDTA, $\mathrm{pH}>13$ ) for 20 minutes, electrophoresis was carried out at $25 \mathrm{~V}(\mathrm{VcM}=0.74 \mathrm{~V} / \mathrm{cm}, 300 \mathrm{~mA})$ for $20 \mathrm{~min}$ followed by neutralization of the slides in $0.4 \mathrm{M}$ Tris $\mathrm{HCl}$ buffer for 15 minutes. Then the slides were drained and immersed in chilled absolute alcohol for 30 minutes for dehydration and then stored in a dry area until staining.
The slides were stained with ethidium bromide $(2 \mu \mathrm{g} / \mathrm{ml})$ and observed under a fluorescent microscope (Imager-A1, Zeiss, Germany) and images were captured under 40X objective. Each slide was coded to avoid observer bias and the images were captured by one person and analysis was carried out by another. A minimum of 50 images were obtained from each slide by scanning the different areas of the slide randomly avoiding the anode end and edges of the slides. The damaged sperms attain a shape of a comet, with the tail region consisting of fragmented DNA and head region having intact DNA. The comet evaluation (percent tail DNA and olive tail moment) of the captured images was performed using Kinetic Imaging software (Komet 5.5).

\section{Sperm wash by swim-up}

One portion of the sperm suspension was mixed with double the volume of pre-warmed EBSS medium supplemented with $0.1 \%$ bovine serum albumin (Cat No. A3311, Sigma Chemical Co. USA) and then centrifuged at $300 \mathrm{~g}$ for $10 \mathrm{~min}$. The pellet was resuspended in the fresh EBSS medium and centrifuged again at $300 \mathrm{~g}$ for $10 \mathrm{~min}$. The resulting pellet was overlaid with $0.3 \mathrm{ml}$ EBSS medium and incubated at $37^{\circ} \mathrm{C}$ for one hour. The DNA integrity by comet assay was assessed in the supernatant and pellet fractions.

\section{Sperm wash by density gradient method}

Approximately $0.5 \mathrm{ml}$ of sperm suspension was layered on a commercially available discontinuous two layer (40\%-80\%) gradient (PureCeption $^{\mathrm{rm}}$, Cat. No.2040\&2080, Sage) in a $14 \mathrm{ml}$ tube. The tubes were centrifuged at $1000 \mathrm{~g}$ for $20 \mathrm{~min}$ at room temperature. Spermatozoa were collected from the different gradients viz. gradient pellet, gradient-80, gradient-40, and gradient supernatant (sample fraction), and were resuspended in EBSS medium and then assessed for DNA integrity.

\section{Combination of density gradient and swim-up method}

The final part of the sperm suspension was processed for the discontinuous density gradient as explained above. The resultant pellet was resuspended in $5 \mathrm{ml}$ of EBSS medium and centrifuged at $300 \mathrm{~g}$ for $10 \mathrm{~min}$. The washing step was repeated as above and the pellet was overlaid with $0.3 \mathrm{ml}$ EBSS medium and incubated at $37^{\circ} \mathrm{C}$ for one hour. The DNA integrity by comet assay was assessed in the supernatant and pellet fractions.

\section{Statistical analysis}

The values were expressed as Mean \pm SEM (standard error of the mean). One way Analysis of Variance (ANOVA) was done to determine significance levels. A P value less than 0.05 was considered as statistically significant.

\section{Results}

A detailed investigations of sperm count, motility, and DNA integrity of pre and post wash fractions have demonstrated the efficacy of the individual methods employed. When we examined the ability of various wash techniques for the extraction of motile sperm in the improved fraction, it was 
found that the mean percentage of motile sperm in both swim-up and density gradient was significantly higher than the combination of swim-up and density gradient method (Table 1). Similarly, the number of spermatozoa recovered is significantly lower in the improved fraction of the combined density gradient/swim-up technique.

We examined all the sperm wash fractions for the sperm DNA integrity by comet assay to determine which fraction effectively holds spermatozoa with aberrant DNA. The amount of tail DNA was not significantly different between the two fractions of swim-up technique (pellet and supernatant) and the unprocessed sperm (Fig. 1A). Similarly, the sperm collected from various sub-fractions after density gradient separation (gradient supernatant, gradient 80 , gradient 40 , and gradient pellet) did not differ significantly with respect to the tail DNA. The amount of tail DNA in the gradient pellet was almost the same as the unprocessed spermatozoa $(9.92 \pm 0.53$ Vs $10.29 \pm 0.52$ ). When these pellets were further processed by swim-up method, the amount of tail DNA dropped significantly $(p<0.05)$ in the swim-up supernatant $(9.92 \pm 0.53$ vs $7.19 \pm 0.43)$. Overall, the amount of tail DNA was significantly reduced $(p<0.01)$ from the un-processed sperm $(10.29 \pm 0.52)$ to the swim-up supernatant (7.19 \pm 0.43$)$ (Fig. 2A).

We have also analyzed the Olive Tail Moment (product of the tail length and the fraction of total DNA in the tail) (17) in the above fractions. The OTM in swim-up fractions did not significantly differ from each other (Fig. 1B). However, the OTM observed in the gradient supernatant $(12.38 \pm 0.68)$ was significantly higher $(\mathrm{p}<0.001)$ than in the unprocessed sperm $(8.58 \pm 0.44)$ and gradient 80 fraction $(7.54 \pm 0.46)$.
Similarly the OTM of the sperm held at gradient 40 fraction $(10.75 \pm 0.63)$ was also significantly higher $(p<0.01)$ than the gradient 80 fraction. As observed in the tail DNA, the OTM was also significantly lower in the spermatozoa recovered from the swim-up fraction of combined density gradient/swim-up method when compared to gradient pellet and unprocessed sperm $(\mathrm{p}<0.05)$ (Fig. 2B).

\section{Discussion}

In this study, we have demonstrated that the combination of density gradient and swim-up method is effective in eliminating DNA damaged mouse spermatozoa. In contrast, when a single wash technique was applied, the amount of DNA damaged sperm in the final population did not differ significantly from the unprocessed population. When we tested the ability of the commonly used swim-up technique in the elimination of DNA damaged sperm, our observation did not show any significant difference in the level of DNA damaged sperm between the pellet and the swim-up fraction. This is in agreement with an earlier study where swim-up technique failed to isolate a population of sperm with a low percentage of nuclear anomalies (7).

It has been previously shown that the semen processing technique itself may either increase or not alter sperm chromatin stability $(10,11)$. Since the issue of iatrogenic sperm DNA damage is being debated, we made an attempt here to evaluate the nuclear integrity of sperm retained in all the sub-fractions of swim-up and density separation. Although progressive motility of spermatozoa is increased after density gradient preparation in

Table 1. Sperm count and motility in the improved fraction of various sperm wash methods

\begin{tabular}{|l|c|c|}
\hline Method & Sperm count (Mean \pm SEM) & Sperm motility (Mean \pm SEM) \\
\hline Swim up & $2.84 \pm 1.81$ & $25.6 \pm 9.6$ \\
\hline Density gradient & $9.52 \pm 7.66$ & $26.4 \pm 7.76$ \\
\hline Density gradient + Swim up & $1.44 \pm 0.42$ & $8.8 \pm 6.8$ \\
\hline
\end{tabular}

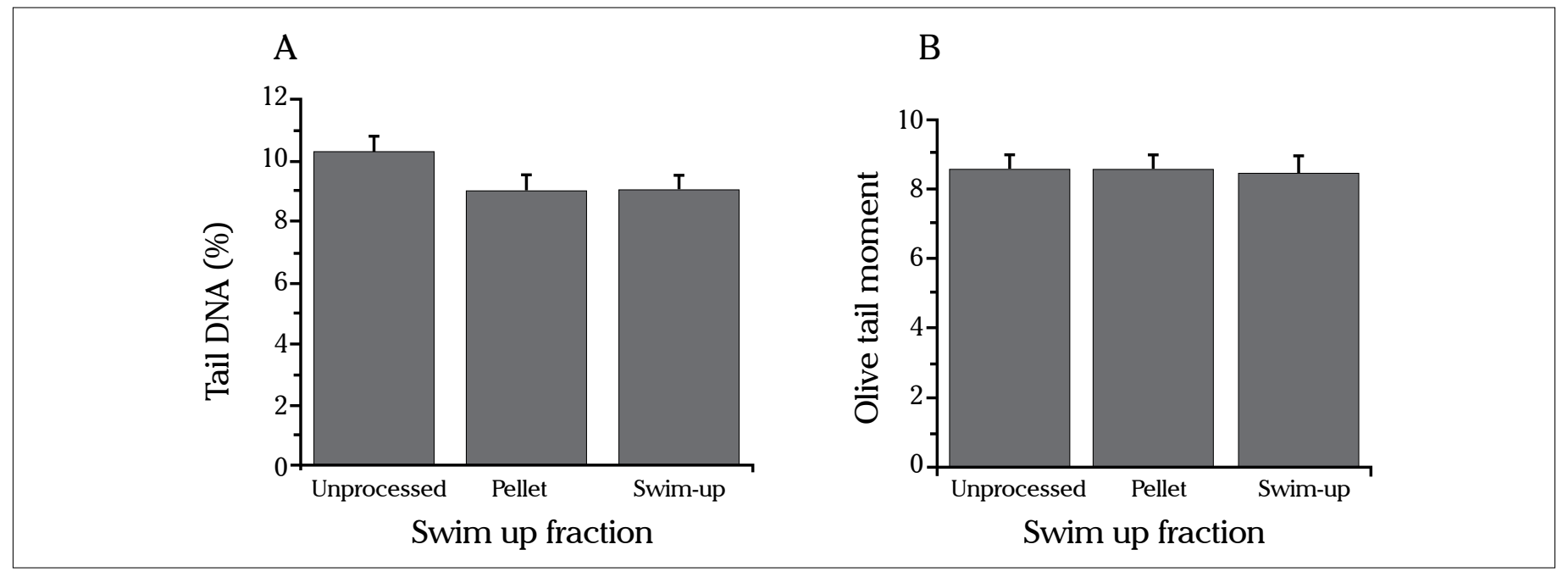

Figure 1. The incidence of sperm DNA damage in the unprocessed and various swim-up fractions $A$. The data representing percent tail DNA. B. Olive tail moment. $\mathrm{P}>0.05$ between all the groups 


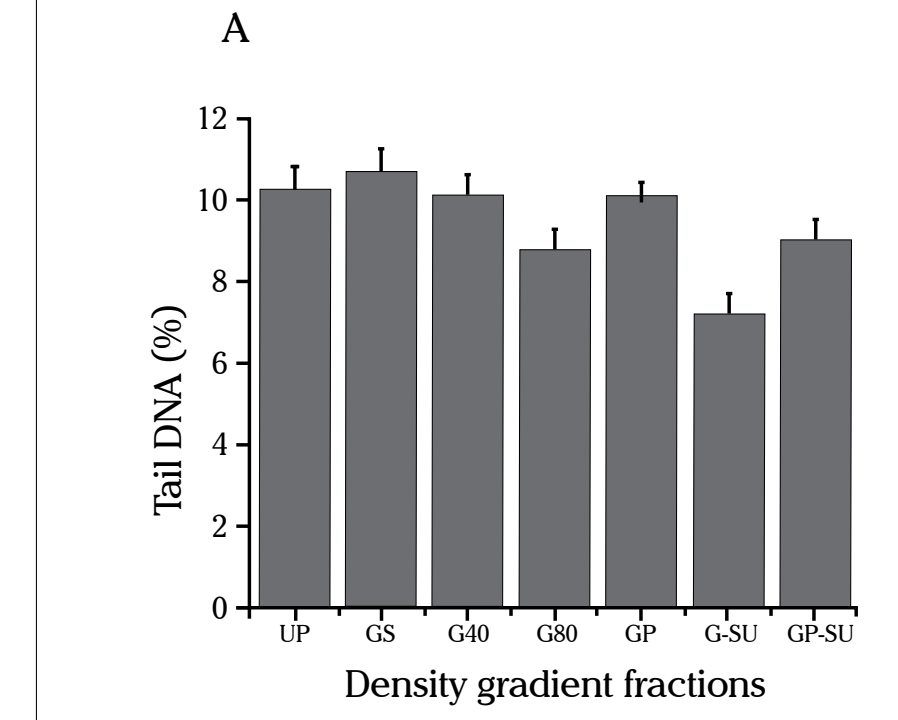

B

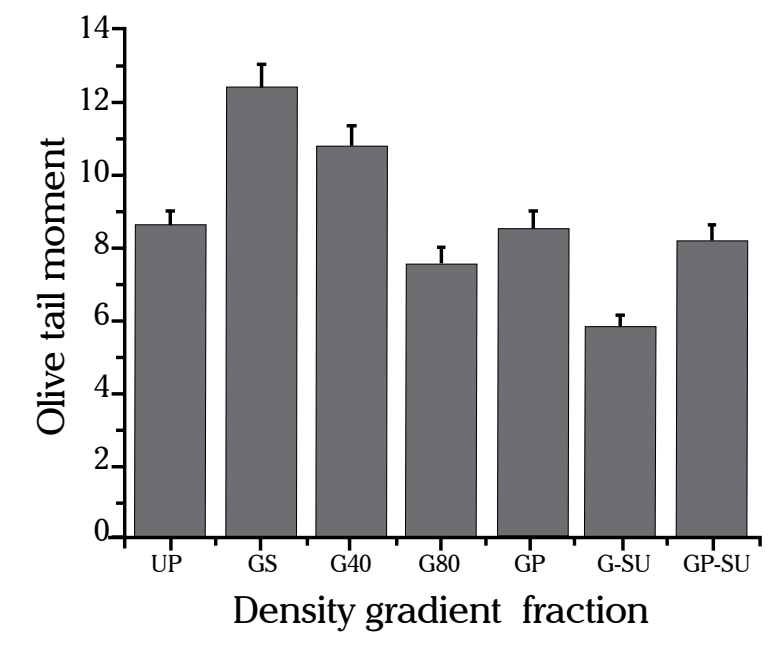

Figure 2. The incidence of sperm DNA damage in the unprocessed sub fractions of density gradient technique and combination of density gradient and swim-up technique (UP: unprocessed sperm, GS: gradient supernatant, G40: gradient 40 fraction, G80: gradient 80 fraction, GP: gradient pellet, G-SU: supernatant fraction after combined gradient and swim-up, GP-SU: pellet fraction after combined gradient and swim-up. A. The data representing percent tail DNA. The amount of tail DNA between UP and G-SU are significantly different $(p<0.01)$. Similarly G-SU and GP-SU are significantly different $(p<0.05)$. B. The level of Olive Tail Moment was significantly different between UP and GS, GS and G80 (p<0.001), G40 and G80 (p<0.01), GP and GP-SU, G-SU and GP-SU (p<0.05)

this study, the number of sperm with intact DNA in the post wash preparation remained unaltered when compared to unprocessed spermatozoa. Furthermore, we noticed a significant number of DNA damaged spermatozoa retained at gradient 40 , and the level of DNA damage in these sperm was significantly higher than the unprocessed sperm. The possible explanations for this observation are either gradient 40 is quite effective in retaining the spermatozoa with nuclear abnormalities or the technique itself induces nuclear abnormalities in spermatozoa, as suggested by other authors $(9,10)$.

An earlier study (12) reported that semen processing by density gradient centrifugation is not generally useful in extracting sperm with intact DNA. This study used the TUNEL assay to detect DNA fragmentations, which is not a very sensitive assay as it detects fragments usually induced by endogenous nucleases (19). In contrast, flow cytometric analysis of density gradient processed samples for apoptosis revealed the superiority of this method in eliminating apoptotic sperm (8). Here we used the alkaline comet assay which detects single strand breaks, double strand breaks and alkali labile sites in the unprocessed sperm, as well as in sperm recovered from all the sub-fractions of swim-up and density gradient methods from which spermatozoa were recovered. Many different comet assay modifications are in use, including alkaline and neutral versions applying different treatments for chromatin decondensation (20). The comet results are known to vary due to a differences in techniques such as use of decondensing agents, electrophoresis time, and other assay conditions. Recent studies reported slightly high level of OTM in the irradiated mice sperm, possibly due to minor modifications in the assay condition $(21,22)$. The reasons for using $\gamma$-irradiated mouse sperm were:- first, to obtain a homogenous population of sperm with DNA damage as the only or dominant pathology and secondly, to thoroughly evaluate these sperm to test the efficacy of the techniques. This is not possible with human ejaculate due to heterogeneity and contamination with non spermatozoa cells.

Sperm preparation for assisted fertilization should aim to minimize the risk that abnormal sperm can have on the reproductive outcome. A reduction in the number of spermatozoa carrying DNA damage in the post-wash population is always a priority, in particular as there is concern regarding developmental delay and a compromised post implantation developmental potential of the embryos derived from the DNA damaged sperm (4). Therefore, a combination of density gradient centrifugation and swim-up technique should be the preferred method for the semen samples with higher amounts of DNA damaged sperm. However, this observation needs to be validated in a large cohort of human ejaculate.

\section{Conflict of interest}

No conflict of interest was declared by the authors.

\section{References}

1. Evenson DP, Larson KL, Jost LK. Sperm chromatin structure assay: its clinical use for detecting sperm DNA fragmentation in male infertility and comparisons with other techniques. J Androl 2002; 23: 25-43. [CrossRef]

2. Aitken RJ, De Iuliis GN. Origins and consequences of DNA damage in male germ cells. Reprod Biomed Online 2007; 14: 727-33. [CrossRef] 
3. Donnelly ET, O`Connell M, McClure N, Lewis SE. Differences in nuclear DNA fragmentation and mitochondrial integrity of semen and prepared human spermatozoa. Hum Reprod 2000; 15: 1552-61. [CrossRef]

4. Adiga SK, Toyoshima M, Shiraishi K, Shimura T, Takeda J, Taga M, et al. p21 provides stage specific DNA damage control to preimplantation embryos. Oncogene 2007; 26: 6141-9. [CrossRef]

5. Adiga SK, Toyoshima M, Shimura T, Takeda J, Uematsu N, Kumar $\mathrm{P}$, et al. Paternal DNA damage suppresses in vitro proliferation of mouse inner cell mass. J Turkish-German Gynecol Assoc 2009; 10: 6-9.

6. Upadhya D, Kalthur G, Kumar P, Rao BS, Adiga SK. Association between the extent of DNA damage in the spermatozoa, fertilization and developmental competence in preimplantation stage embryos. J Turkish-German Gynecol Assoc 2010; 11: 182-6. [CrossRef]

7. Sakkas D, Manicardi GC, Tomlinson M, Mandrioli M, Bizzaro D, Bianchi PG, et al. The use of two density gradient centrifugation techniques and the swim-up method to separate spermatozoa with chromatin and nuclear DNA anomalies. Hum Reprod 2000; 15: 1112-6. [CrossRef]

8. Ricci G, Perticarari S, Boscolo R, Montico M, Guaschino S, Presani G. Semen preparation methods and sperm apoptosis: swim-up versus gradient-density centrifugation technique. Fertil Steril 2009; 91: 632-8. [CrossRef]

9. Mortimer D. Sperm preparation techniques and iatrogenic failures of in-vitro fertilization. Hum Reprod 1991; 6: 173-6.

10. Zini A, Mak V, Phang D, Jarvi K. Potential adverse effect of semen processing on human sperm deoxyribonucleic acid integrity. Fertil Steril 1999; 72: 496-9. [CrossRef]

11. Zini A, Finelli A, Phang D, Jarvi K. Influence of semen processing technique on human sperm DNA integrity. Urology 2000; 56: 1081-4. [CrossRef]

12. Stevanato J, Bertolla RP, Barradas V, Spaine DM, Cedenho AP, Ortiz V. Semen processing by density gradient centrifugation does not improve sperm apoptotic deoxyribonucleic acid fragmentation rates. Fertil Steril 2008; 90: 889-90. [CrossRef]

13. Colleu D, Lescoat D, Gouranton J. Nuclear maturity of human spermatozoa selected by swim-up or by Percoll gradient centrifugation procedures. Fertil Steril 1996; 65: 160-4.

14. Golan R, Shochat L, Weissenberg R, Soffer Y, Marcus Z, Oschry Y, et al. Evaluation of chromatin condensation in human spermatozoa: a flow cytometric assay using acridine orange staining. Mol Hum Reprod 1997; 3: 47-54. [CrossRef]

15. Hammadeh ME, Kühnen A, Amer AS, Rosenbaum P, Schmidt W. Comparison of sperm preparation methods: effect on chromatin and morphology recovery rates and their consequences on the clinical outcome after in vitro fertilization embryo transfer. Int $\mathrm{J}$ Androl 2001; 24: 360-8. [CrossRef]

16. Singh NP, McCoy MT, Tice RR, Schneider EL. A simple technique for quantitation of low levels of DNA damage in individual cells. Exp Cell Res 1988; 175: 184-91. [CrossRef]

17. Olive PL, Banáth JP, Durand RE. Heterogeneity in radiation-induced DNA damage and repair in tumor and normal cells measured using the "comet" assay. Radiat Res 1990; 122: 86-94. [CrossRef]

18. Adiga SK, Kalthur G, Kumar P. Comparative Evaluation of Carbon Dioxide and Carbon Dioxide Free System in Sperm Extraction by Swim-up Technique. J Turkish-German Gynecol Assoc, 2007; 8 : 194-7.

19. Gavrieli Y, Sherman Y, Ben-Sasson SA. Identification of programmed cell death in situ via specific labeling of nuclear DNA fragmentation. J Cell Biol 1992; 119: 493-501. [CrossRef]

20. Speit G, Vasquez M, Hartmann A. The comet assay as an indicator test for germ cell genotoxicity. Mutat Res 2009; 681: 3-12. [CrossRef]

21. Haines GA, Hendry JH, Daniel CP, Morris ID. Germ cell and dosedependent DNA damage measured by the comet assay in murine spermatozoaa after testicular X-irradiation. Biol Reprod 2002; 67: 854-61. [CrossRef]

22. Cordelli E, Fresegna AM, Leter G, Eleuteri P, Spanò M, Villani P. Evaluation of DNA damage in different stages of mouse spermatogenesis after testicular X irradiation. Radiat Res 2003;160:443-51. 